We strongly believe that this technique may occasionally be an attractive approach when pedicled ITA is not long enough to be used for sequential bypass grafting.

\section{References}

1. Del Campo C. Pedicled or skeletonized? A review of the internal thoracic artery graft. Texas Heart Inst J. 2003;30:170-5.

2. Voutilainen SM, Jarvinen AA, Verkkala KA, Keto PE, Heikkinen LO, Voutilainen PE, et al. Angiographic 20-year follow-up of 61 consecutive patients with internal thoracic artery grafts. Ann Surg. 1999;229: 154-8.

3. Ueda T, Taniguchi S, Kawata T, Mizuguchi K, Nakajima M, Yoshioka A. Does skeletonization compromise the integrity of internal thoracic artery graft? Ann Thorac Surg. 2003;75:1429-33.
4. Calafiore AM, Vitolla G, Iaco AL, Fino C, Di Giammarco G, Marchesani $\mathrm{F}$, et al. Bilateral internal mammary artery grafting: midterm results of pedicled versus skeletonized conduits. Ann Thorac Surg. 1999;67:1637-42.

5. Calafiore AM, Contini M, Vitolla G, Di Mauro M, Mazzei V, Teodori $\mathrm{G}$, et al. Bilateral internal thoracic artery grafting: long-term clinical and angiographic results of in situ versus Y grafts. $J$ Thorac Cardiovasc Surg. 2000;120:990-8.

6. Biglioli P, Almanni F, Antona SC, Sala A, Susini G. Coronary-coronary bypass: theoretical basis and techniques. J Cardiovasc Surg. 1987;28: 333-5.

7. Nottin R, Grinda JM, Anidjar S, Folliguet T, Detroux M. Coronarycoronary bypass graft: an arterial conduit-sparing procedure. J Thorac Cardiovasc Surg. 1996;112:1223-30.

8. Barboso G, Rusticali F. Proximal internal mammary in situ graft and distal coronary-coronary graft to revascularize left anterior descending coronary artery. Texas Heart Inst J. 2000;27:70-1.

\title{
Activated recombinant factor VII for refractory bleeding during extracorporeal membrane oxygenation
}

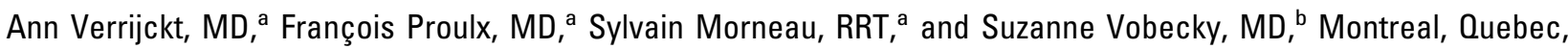 \\ Canada
}

$\mathrm{H}$ emorrhagic complications are a major concern for patients undergoing extracorporeal membrane oxygenation (ECMO) after cardiac surgery. Transfusions of platelets, fresh-frozen plasma and cryoprecipitates are commonly used to improve hemostasis, sometimes in association with antifibrinolytic agents or protease inhibitors.

Activated recombinant factor VII (rFVIIa; Novoseven, Novo Nordisk, Denmark) was originally envisioned for the treatment of bleeding in patients with hemophilia in whom inhibiting antibodies to factor VIII developed. Most recently, rFVIIa has also been successfully used among critically ill patients with impaired thrombin generation and severe hemorrhage after major trauma, liver failure or transplantation, and overdose of oral anticoagulants. We report the case of a child undergoing ECMO with refractory thoracic bleeding, which was controlled by a single dose of rFVIIa $(30 \mu \mathrm{g} / \mathrm{kg})$.

\footnotetext{
From the Department of Pediatrics, Section of Intensive Care Medicine, and the Department of Pediatric Surgery, Section of Cardiovascular Surgery, , Sainte-Justine Hospital, University of Montreal, Montreal, Quebec, Canada.

Received for publication Dec 8, 2003; accepted for publication Dec 24, 2003.

Address for reprints: Ann Verrijckt, MD, Department of Pediatrics, SainteJustine Hospital, 3175 Chemin Côte Sainte-Catherine, Montreal (Quebec), Canada, H3T-1C5 (E-mail: annverrijckt@yahoo.com).

J Thorac Cardiovasc Surg 2004;127:1812-3

$0022-5223 / \$ 30.00$

Copyright $\odot 2004$ by The American Association for Thoracic Surgery

doi:10.1016/j.jtcvs.2003.12.021
}

\section{Clinical Summary}

A term, 3.2-kg male neonate had dextro-transposition of the great arteries diagnosed on the first day after birth. Prostaglandin $\mathrm{E}_{1}$ infusion was started, and a Rashkind atrial septostomy was performed on the second day after birth. The arterial switch operation was postponed until the 12th day of life because of intracerebral hemorrhages with subdural, subarachnoidal, and intraventricular components (diameter $8 \mathrm{~mm}$ ).

The platelet count and coagulogram were within normal limits. Results of screening studies for congenital coagulation factor deficiencies were also normal. Although the child remained free of symptoms and repeated cerebral computed tomography showed a decreased size of the hematoma, he received seizure prophylaxis with phenobarbital. After uneventful anesthetic induction, an arterial switch operation was performed, with ligation of the arterial duct and closure of the atrial septostomy under cardiopulmonary bypass $\left(221\right.$ minutes) with moderate hypothermia $\left(29^{\circ} \mathrm{C}\right)$ and aortic crossclamping (83 minutes). Aprotinin was administered during surgery, followed by protamine during weaning. Abnormal circumflex coronary artery originating from the right coronary artery was felt to be responsible for persistent left ventricular failure, leading to unsuccessful weaning from cardiopulmonary bypass and the requirement for venoarterial ECMO support with a Carmeda coated circuit (Medtronic, Minneapolis, Minn). During the first 2 days, the postoperative phase was characterized by severe bleeding from the chest tubes $(10 \mathrm{~mL} / \mathrm{kg} / \mathrm{h})$, despite massive transfusion of blood products $(7.7 \mathrm{~mL} / \mathrm{kg} / \mathrm{h}$ packed red blood cells, $4.1 \mathrm{~mL} / \mathrm{kg} / \mathrm{h}$ platelets, and $2.6 \mathrm{~mL} / \mathrm{kg} / \mathrm{h}$ fresh-frozen plasma) and calcium chloride.

Surgical reexplorations at 24 and 36 hours after the operation failed to reveal any active surgical bleeding site. Because of persistent hemorrhage from the thoracic chest tubes, aminocaproic 
acid $(100 \mathrm{mg} / \mathrm{kg})$ was given intravenously, without any effect. Subsequently, rFVIIa (30 $\mu \mathrm{g} / \mathrm{kg})$ was administered intravenously. The hematologic parameters before and after rFVIIa administration are shown in Table 1. On the following days, the patient's condition remained stable with a significant reduction in the amount of blood loss and without any apparent thrombotic event. On the fifth postoperative day, the child was weaned from ECMO. Despite maximal supportive therapy, he died of persistent left ventricular failure on the 11th postoperative day. Autopsy was refused by the parents.

\section{Discussion}

In this study, we noted that a single $30-\mu \mathrm{g} / \mathrm{kg}$ dose of rFVIIa decreased persistent thoracic bleeding associated to cardiac ECMO. Similar findings have been reported by Tobias and colleagues, ${ }^{1}$ who used $70 \mu \mathrm{g} / \mathrm{kg} \mathrm{rFVIIa}$ in a 4-month-old child who had postoperative hemorrhage after repair of an atrial septal defect. Recently, Leibovitch and associates ${ }^{2}$ reported the successful uncomplicated use of 4 doses of rFVIIa (100 $\mu \mathrm{g} / \mathrm{kg}$ in each dose) in the treatment of pulmonary hemorrhage after cardiac surgery in a 10-week-old infant.

During ECMO, nonsurgical bleeding may result from heparin overdose or consumptive coagulopathy related to hemodilution, thrombocytopenia, decreased platelet function, deficiency of coagulation factors, and hyperfibrinolysis. In additional to conventional therapy with transfusion of blood components, antifibrinolytic agents may decrease the bleeding tendency at the site of tissue damage without significant risk of vascular thrombosis. When these conventional therapies fail, as in our case, rFVIIa becomes a potentially interesting alternative. This drug may bind tissue factor at sites of vascular damage, thereby leading to thrombin formation, a process involving factors IX and X. Alternatively rFVIIa may activate factor $\mathrm{X}$ on activated platelets independently of the presence of tissue factor. ${ }^{3-4}$

In addition, rFVIIa may play a significant role as a more general hemostatic agent beyond its indications in the treatment of hemophilia complicated by inhibiting antibodies. Experience with its use in cardiac surgery remains limited, mainly out of fear of thrombotic complications in patients with underlying atherosclerotic disease and areas of tissue factor expression in addition to their bleeding source on atherosclerotic plaques. The successful perioperative or postoperative use of rFVIIa has been reported in a limited number of adult cardiac surgery patients without any apparent thrombotic event. However, Bui and colleagues ${ }^{5}$ reported that the use of rFVIIa $(90 \mu \mathrm{g} / \mathrm{kg})$ followed by administration of activated prothrombin complex in a patient undergoing ECMO resulted in massive thrombosis of the circuit and death.
TABLE 1. Hematologic parameters before and after recombinant activated factor VII (rFVIla) during venoarterial extracorporeal membrane oxygenation

\begin{tabular}{lcc}
\hline & Before & After \\
\hline Chest tube bleeding* $(\mathrm{mL} /[\mathrm{kg} \cdot \mathrm{h}])$ & 9.1 & 3.5 \\
Platelet count $\left(\mathrm{cells} / \mathrm{mm}^{3}\right)$ & 89000 & 125,000 \\
Prothrombin time $(\mathrm{s}) \dagger$ & 15.3 & 10 \\
International normalized ratio $\dagger$ & 1.24 & 0.72 \\
Activated partial thromboplastin time† (s) & 135 & 114 \\
Activated clotting time $\ddagger(\mathrm{s})$ & 164 & 148 \\
\hline
\end{tabular}

* Represents the mean chest tube drainage during 4 hours before $(41,26$, $28,22 \mathrm{~mL})$ and after $(22,4,15,5 \mathrm{~mL})$ the use of $\mathrm{rFVIla}(30 \mu \mathrm{g} / \mathrm{kg})$. Because rFVIIa was administered half an hour after the last measurement of thoracic tube drainage, which was calculated on an hourly basis, data during the first hour most likely underestimate the effect of the maneuver. tRepresents the prothrombin time, international normalized ratio, and activated partial thromboplastin time before and 30 minutes after rFVIla. The prothrombin time increased to 12.1 (international normalized ratio 0.92 ) 4 hours later.

‡Heparin was administered before $(45 \mathrm{U} / \mathrm{kg} / \mathrm{h})$ and after $(72 \mathrm{U} / \mathrm{kg} / \mathrm{h}) \mathrm{rFVIla}$.

In conclusion, we report here the first case of a child undergoing ECMO with refractory thoracic bleeding that was controlled with a single dose of rFVIIa. We emphasize that the risk-benefit ratio and the cost-effectiveness of rFVIIa in this population remain unclear. Further characterization of the mechanisms of action of rFVIIa may lead to well-designed, controlled studies.

\section{References}

1. Tobias JD, Berkenbosch JW, Russo P. Recombinant factor VIIa to treat bleeding after cardiac surgery in an infant. Pediatr Crit Care Med. 2003;4:49-51

2. Leibovitch L, Kenet G, Mazor K, Matok I, Vardi A, Barzilay Z, et al. Recombinant activated factor VII for life-threatening pulmonary hemorrhage after pediatric cardiac surgery. Pediatr Crit Care Med. 2003; 4:444-6.

3. Ten Cate H, Bauer K, Levi M, Edgington TS, Sublett RD, Barzegar S, et al. The activation of factor $\mathrm{X}$ and prothrombin by recombinant factor VIIa in vivo is mediated by tissue factor. J Clin Invest. 1993;92:120712.

4. Lisman T, Moschatis S, Nieuwenhuis K, De Groot PG. Recombinant factor VIIa enhances deposition of platelets with congenital or acquired $\alpha \mathrm{IIb} \beta 3$ deficiency to endothelial cell matrix and collagen under conditions of flow via tissue factor-independent thrombin generation. Blood. 2003;101:1864-70.

5. Bui JD, Despotis GD, Trulock EP, Patterson GA, Goodnough LT. Fatal thrombosis after administration of activated prothrombin complex concentrates in a patient supported with extracorporeal membrane oxygenation who had received activated recombinant factor VII. $J$ Thorac Cardiovasc Surg. 2002;124:852-4. 